\title{
Mediator of RNA Polymerase II Transcription Subunit 12
}

National Cancer Institute

\section{Source}

National Cancer Institute. Mediator of RNA Polymerase II Transcription Subunit 12. NCI Thesaurus. Code C98212.

Mediator of RNA polymerase II transcription subunit 12 (2177 aa, $\sim 243 \mathrm{kDa}$ ) is encoded by the human MED12 gene. This protein plays a role in the initiation of transcription. 